\title{
Mandatory Corporate Social Responsibility: A Utilitarian and Deontological Perspective
}

\author{
Harshita Jain \\ American Embassy School, New Delhi, India \\ Email: harshitajain0205@gmail.com
}

How to cite this paper: Jain, H. (2020). Mandatory Corporate Social Responsibility: A Utilitarian and Deontological Perspective. Open Journal of Business and Management, 8, 2278-2284.

https://doi.org/10.4236/ojbm.2020.85139

Received: August 20, 2020

Accepted: September 18, 2020

Published: September 21, 2020

Copyright (อ 2020 by author(s) and Scientific Research Publishing Inc. This work is licensed under the Creative Commons Attribution International License (CC BY 4.0).

http://creativecommons.org/licenses/by/4.0/ (c) (i) Open Access

\begin{abstract}
Most companies engage in some form of corporate social responsibility, yet very few would support legislation to make such activities mandatory. On the other hand, social activists and environment protectors strongly advocate for such policies. However, the final decision rests in the hands of the government. Therefore, this paper analyses two different ethical frameworks: utilitarian and deontological, to evaluate if it is ethical for governments to obligate companies to follow their policies on corporate social responsibility. For the utilitarian theory, the paper discusses the consequences of mandatory corporate social responsibility (with direct examples from India), including the reduction of greenwashing and the increase in the prosperity of social entrepreneurship and the overall welfare of a nation. In contrast, the contradicting obligations of a government, such as protecting the freedom of choice and ensuring the well-being of its citizens, are the basis of the deontological discussion. Ultimately, the ethicality of making corporate social responsibility mandatory depends on the moral priorities of the government. Still, it is essential to note that these policies' specifics can be adapted to promote both self-regulation and the common good.
\end{abstract}

\section{Keywords}

Corporate Social Responsibility, Triple Bottom Line, Utilitarianism, Deontology, Greenwashing, Government Regulation

\section{Introduction}

For many years, philosophers have argued that businesses will maximise their benefits when pursuing the single bottom line approach of profitability (Altman \& Berman, 2011). However, as environmentalists and activists urged companies to focus on sustainable development, businesses' focus was no longer limited to 
making a profit. In the mid-1990s, John Elkington coined the term Triple Bottom Line (TBL) to introduce a new "accounting framework that incorporates three dimensions of [a business's] performance: social, environmental and financial." This sustainable ${ }^{1}$ form of measuring corporate success is commonly referred to as the 3Ps: people, planet, and profit (Slaper \& Hall, n.d.). As a result of the TBL, businesses, non-government organisations (NGOs), and governments have initiated different programs/policies to ensure their long-term goals are sustainable (and in some cases, profitable).

\subsection{Corporate Social Responsibility}

Moreover, to customers, who are more conscious of the consequences of their decisions, buying an ethically manufactured product from a sustainable, trustworthy company has become more relevant as the years have passed. Many businesses have accommodated these developments by adopting a more proactive stance on corporate social responsibility (CSR): "a management concept whereby companies integrate social and environmental concerns in their business operations" (United Nations Industrial Development Organization, n.d.). Furthermore, the concept implies the need for businesses to go beyond the law to protect the interest of all its stakeholders, such as the environment, their employees, and the communities they operate within (University of Texas, 2018). In other words, CSR is a method through which companies balance their triple bottom line goals with their stakeholders' expectations.

CSR offers multiple benefits to firms, including long-term self-interest (in the form of higher profit), enhanced public image, and greater stakeholder interest (Davis, 1973). Consequently, many multinational enterprises, such as CocaCola, Disney, and Microsoft, realigned their objectives to promote sustainability by adopting CSR-based targets (The CocaCola Company, 2019; The Walt Disney Company, 2019; Microsoft Corporation, 2019). Even though CSR programs started as voluntary practices, governments soon began to intervene. For example, in 2013, India became the first country to introduce a mandatory CSR policy under the Companies Act (Government of India, 2013). The nature of this decision has been criticised by many; however, this paper explores the utilitarian and deontological frameworks to argue that it is indeed ethical for a government to mandate CSR policies and regulations for its businesses.

\subsection{Research Methodology}

The research is structured to demonstrate how mandatory CSR supports the utilitarian perspective and opposes elements of the deontological framework. After establishing the parameters of utilitarianism, the argument uses India as an example to demonstrate how compulsory CSR has led to reduced greenwashing and enhanced social and environmental progress of the country. Some coun-

${ }^{1}$ Sustainability is the "development that meets the needs of the present without compromising the ability of future generations to meet their own needs" (Our common future, 1990). 
ter-arguments, such as lack of efficiency in executing mandatory CSR policies, are addressed as well.

Similarly, the paper examines the morality of mandatory CSR through the deontological perspective: focusing on the duty of the government, and the controversy encompassing it. The discussion manifests the diverse range of opinions economists and philosophers have on intervention ethics and elaborates on the benefits and shortcomings of each. Moreover, this paper highlights how obligatory CSR policies differ around the world, and the role of ethics varies based upon the specifications of the policy itself. Finally, the idea of "meta-regulation", a unique approach to mandatory CSR policies that incorporates features of both utilitarianism and deontology, is evaluated as a possible solution.

\section{Utilitarianism}

According to the Stanford Encyclopedia of Philosophy, utilitarianism is when "an act is morally right if and only if that act maximises the good". By this definition, an action that increases the world's net good is ethical and compulsory CSR is no exception to this rule. Research exemplifies that government regulations help reduce greenwashing. While the interpretation of greenwashing is unsettled, the most agreed-upon definition by Greenpeace claims that greenwashing is "the act of misleading consumers regarding the environmental practices of a company or the environmental benefits of a product or service" (as cited by Gatti et al., 2019). Most ethicists deem greenwashing to be unethical due to its misleading nature and its tendency to create an illusion of environmental sustainability that eventually leads to more considerable consumer scepticism (MacDonald, n.d.). A study by Gatti et al. (2019) conveyed that an increase in government regulation of CSR practices would diminish the level of greenwashing due to the heightened levels of accountability and cross-checking. Hence, when governments reduce the harm (inflicted through unethical practices such as greenwashing) by implementing mandatory CSR policies, they raise the net good in the world, an ethical decision from a utilitarian point of view.

Conversely, some have debated that governments can maximise the net good more effectively by collecting the CSR money as tax and allocating it as one uniformed body (Arun, 2019). While it is reasonable to consider that governments will be more capable of processing the money more efficiently than numerous companies with their corporate agendas, it is also important to remember that politicians have self-interest. Utilitarianism is about increasing the maximum amount of good for the maximum number of people (Sinnott-Armstrong, 2019). Nevertheless, when politicians decide the government's money-allocation, they display a natural bias towards their voters. By collecting the CSR money as a form of additional corporate tax, governments would end up increasing the good of a small group significantly, but would not be able to improve the benefit for a more diversified society as the CSR programs. The lack of divergence is because the self-interest of various organisations is more varied than that of a 
single-government. In essence, making CSR mandatory is ethical as it would distribute the net good across a broader range of people.

\section{India: A Case Study}

As mentioned earlier, India was the first country to make CSR mandatory and has been a pioneer in establishing standards for countries that followed. India serves as an essential real-world example of the utilitarian vision of mandatory CSR as the benefits/drawbacks have become easily measurable over the years. The policy in India requires each enterprise to utilise $2 \%$ of their average profits for CSR programs and employ a company representative responsible for accounting for all the financial transactions when they are processed by the government (Government of India, 2013).

Reports prove that the initiation of obligatory CSR practices has led to an increase in structured social and environmental ventures, which had been previously ignored by most companies; also, it has raised the number of NGOs and social entrepreneurs actively working towards the betterment of society (Sundar, 2018). From a utilitarian framework, India's success extensively categorises the decision of shifting from voluntary to mandatory CSR as ethical. It is also important to note that the full effects of mandatory CSR have not been internalised yet, as the Indian government has many shortcomings in its enforcement of the law (Arun, 2019). Therefore, if all the money designated for CSR were managed appropriately, the total benefit of compulsory CSR legislation would be further maximised.

In summary, from a utilitarian perspective, it is ethical for governments to mandate corporations to engage in CSR activities as it reduces greenwashing and improves social and environmental prosperity for the greater good of the country.

\section{Deontology}

Unlike utilitarianism, deontology determines the righteousness of actions by "the moral quality of acts in the principles or maxims on which the agent acts and not primarily in those acts' effects on others". In this model of ethics, "what makes a choice right is its conformity with a moral norm" (Alexander, \& Moore, 2016). From a corporate viewpoint, deontology asserts that a business has duties/responsibilities to specific stakeholders, and it is the motivations towards these stakeholders that hold more considerable significance than the actual consequences ("Moral and ethical role of government," 2018). Likewise, a government must consider their duties and responsibilities towards their citizens before addressing legal declarations. Many deontologists argue that one of the government's primary responsibility is to protect and enforce the laws; nevertheless, whether the law is ethical or not is still a very controversial debate.

The analysis of deontology regarding the role of the government is complicated as different cultures and philosophies prioritise morals differently. In par- 
ticular, many laissez-faire economists promote anti-government intervention policies and proclaim that the government must allow capitalist economies to function naturally (Emerald Group Publishing Limited, 2000). On the other hand, philosophers such as Aristotle believe the authorities should govern for the "common good" (Diggs, 1973). Further, the distinctions significantly expand when considering the various types of government, including democracy, monarchy, aristocracy, and their relationships with their economy and citizens.

This dilemma associated with intervention ethics pertains to the deontological ethics of mandatory CSR also. Many free-market economists are against making CSR activities binding; others maintain that the government is responsible for "mandating, facilitating, partnering (with), and endorsing" CSR activities (Dentchev et al., 2016). Either way, it is essential to recognise that not all commitments of the government are equally weighted. Should governments preserve the fundamental rights of their citizens? Or should the government act for the greater good? These questions do not have a straightforward answer and differ based on the policy's specifics. For instance, in many cases, mandatory CSR co-exists with features of voluntary CSR in the form of "meta-regulation" governments (like India) mandate the amount of money that businesses must spend but provide them with the freedom to determine how and where they spend their money as long as it abides with the standard contractual protocols (Montiel-Justo, 2019). In this scenario, the government can accomplish both their commitment to protecting their citizens' rights and their promise to serve the greater good by assisting the majority of their citizens.

In summary, deontology proposes a nuanced perspective on the subject of the ethics of compulsory CSR. Even though there is no definite solution to the issue (as diverse philosophies and authorities interpret the government's role differently), there are alternatives (i.e., meta-regulation) for a government to satisfy their duties to all stakeholders through the incorporation of voluntary aspects in their mandatory CSR policies.

\section{Conclusion}

Ethics is frequently overlooked in debates concerning the government's position in shaping corporate social responsibility practices. Nonetheless, it is a crucial determinant to consider when constituting law-abiding declarations. Thus, this paper evaluates the ethicality of governments making corporate social responsibility mandatory through the utilitarian and deontological frameworks. The utilitarian viewpoint affirms that making CSR compulsory for enterprises is ethical. It benefits the greater good; it diminishes greenwashing and strengthens the social and environmental prosperity by aiding a more diverse society of people than a political agenda of a nation. In addition, the regulations align with the goals of TBL to promote more sustainable business development. On the other hand, the deontological perspective portrays a grey zone as the duty of a government is still disputed. While it can be contended that mandatory CSR is un- 
ethical because a government infringes on its citizens' rights, it is equally necessary to note that a democratic government is also accountable for maintaining the welfare of its citizens. In this regard, the utilitarian outlook is also a part of the deontological ethics as it urges a government to take a proactive stance on advocating for the common good.

In conclusion, mandatory corporate social responsibility can be ethical and unethical. It depends on an individual or government's moral values as one cannot claim that one ethical framework is more reliable than the other.

\section{Limitations}

Even though this paper endeavours to provide insightful analysis of the relationship between ethics and mandatory CSR, there are some limitations which offer opportunities for further research. Firstly, the major weakness in this research is that ethical frameworks, apart from utilitarianism and deontology, are not considered in this debate. Each theory of ethics reflects distinctive principles and a more thorough evaluation of mandatory CSR would critique multiple other viewpoints. Secondly, the selection of data is only limited to the case study of India. Although India serves as the pioneer nation, restricting the scope of the research could exclude some crucial examples that may reinforce or undermine the reasoning presented above. Lastly, solely the duty of the government was developed in the deontology segment, when in reality, several different associations and individuals are involved in the process (i.e., businesses, politicians, citizens), and they have another set of responsibilities that must be examined.

\section{Conflicts of Interest}

The author declares no conflicts of interest regarding the publication of this paper.

\section{References}

(1990). Our Common Future. World Commission on Environment and Development. http://www.un-documents.net/our-common-future.pdf

(2018). Moral and Ethical Role of Government. UKEssays. https://www.ukessays.com/essays/politics/moral-and-ethical-role-of-government-politi cs-essay.php?vref=1

Alexander, L., \& Moore, M. (2016). Deontological Ethics. In E. N. Zalta (Ed.), Stanford Encyclopedia of Philosophy. Stanford: Metaphysics Research Lab, Stanford University. https://plato.stanford.edu/entries/ethics-deontological/\#DeoThe

Altman, D., \& Berman, J. (2011). The Single Bottom Line. http://w4.stern.nyu.edu/economics/docs/workingpapers/2011/Altman\%206-13-11.pdf

Arun, T. K. (2019). View: How Mandated “Corporate Social Responsibility" Can Be Wasteful. The Economic Times.

https://economictimes.indiatimes.com/news/company/corporate-trends/view-how-ma ndated-corporate-social-responsibility-can-be-wasteful/articleshow/70515680.cms?fro $\underline{\mathrm{m}=\mathrm{mdr}}$ 
Davis, K. (1973). The Case for and against Business Assumption of Social Responsibilities. Academy of Management Journal, 16, 312-322. https://doi.org/10.5465/255331

Dentchev, N. A., Haezendonck, E., \& Van Balen, M. (2016). The Role of Governments in the Business and Society Debate. Business \& Society, 56, 527-544. https://doi.org/10.1177/0007650315586179

Diggs, B. J. (1973). The Common Good as a Reason for Political Action. Ethics, 83, 283-293. https://doi.org/10.1086/291887

Emerald Group Publishing Limited (2000). The Philosophy of Laissez-Faire and the Laissez-Faire State. American Economics, 18, 280-281.

Gatti, L., Seele, P., \& Rademacher, L. (2019). Grey Zone In-Greenwash Out. A Review of Green Washing Research and Implications for the Voluntary-Mandatory Transition of CSR. International Journal of Corporate Social Responsibility, 4, Article No. 6. https://doi.org/10.1186/s40991-019-0044-9

Government of India (2013). The Companies Act. Ministry of Corporate Affairs Government of India. https://www.mca.gov.in/Ministry/pdf/CompaniesAct2013.pdf

MacDonald, C. (n.d.). Greenwashing. BusinessEthics.ca-Your Resource for Business Ethics. http://www.businessethics.ca/greenwashing/

Microsoft Corporation (2019). CSR Annual Report.

https://www.microsoft.com/en-us/corporate-responsibility/reports-hub

Montiel-Justo, A. A. (2019). (PDF) Should CSR Be Mandatory, Voluntary or Both? https://www.researchgate.net/publication/333161843 Should CSR be mandatory vol untary or both

Sinnott-Armstrong, W. (2019). Consequentialism. In E. N. Zalta (Ed.), Stanford Encyclopedia of Philosophy. Stanford: Metaphysics Research Lab, Stanford University. https://plato.stanford.edu/entries/consequentialism

Slaper, T. F., \& Hall, T. J. (n.d.). The Triple Bottom Line: What Is It and How Does It Work? Bloomington, IN: Indiana Business Research Center, Kelley School of Business, Indiana University. https://www.ibrc.indiana.edu/ibr/2011/spring/article2.html

Sundar, P. (2018). Five Years after CSR Became Mandatory, What Has It Really Achieved? The Wire.

https://thewire.in/business/five-years-after-csr-became-mandatory-what-has-it-really-a chieved

The CocaCola Company (2019). Business \& Sustainability Report. The Coca-Cola Company: Refresh the World. Make a Difference.

https://www.coca-colacompany.com/content/dam/journey/us/en/reports/coca-cola-bu siness-and-sustainability-report-2019.pdf

The Walt Disney Company (2019). Corporate Social Responsibility Update.

https://thewaltdisneycompany.com/app/uploads/2020/02/CSR2019Report.pdf

United Nations Industrial Development Organization (n.d.). What Is CSR? UNIDO. https://www.unido.org/our-focus/advancing-economic-competitiveness/competitive-tr ade-capacities-and-corporate-responsibility/corporate-social-responsibility-market-int egration/what-csr

University of Texas (2018). Corporate Social Responsibility. Ethics Unwrapped. https://ethicsunwrapped.utexas.edu/glossary/corporate-social-responsibility 